\title{
Economic Americanness and defensive inclusion: social location and young citizens' conceptions of national identity
}

\section{Citation}

Warikoo, N., \& Bloemraad, I. 2018. Economic Americanness and defensive inclusion: Social location and young citizens' conceptions of national identity. Journal of Ethnic and Migration Studies, 44(5): 736-753. DOI: 10.1080/1369183x.2017.1329006

\section{Permanent link}

http://nrs.harvard.edu/urn-3:HUL.InstRepos:41329221

\section{Terms of Use}

This article was downloaded from Harvard University's DASH repository, and is made available under the terms and conditions applicable to Open Access Policy Articles, as set forth at http:// nrs.harvard.edu/urn-3:HUL.InstRepos:dash.current.terms-of-use\#OAP

\section{Share Your Story}

The Harvard community has made this article openly available. Please share how this access benefits you. Submit a story.

Accessibility 


\title{
Economic Americanness and Defensive Inclusion:
}

Social Location and Young Citizens' Conceptions of National Identity

\begin{abstract}
What does it mean to be "American"? Drawing on in-depth interviews with 76 undergraduates attending elite universities and 72 teenaged citizen children of immigrants living in mostly lowincome households, we identify understudied economic narratives of Americanness: as futureoriented economic opportunities for elite undergraduates or stratified notions of current economic condition among immigrant-origin teens. We also find, depending on social location, that economic notions of Americanness overlap with other boundaries: whiteness for some immigrant-origin youth, and civic membership for elite undergraduates. Elite students place themselves at the center of Americanness; immigrant-origin youth, even though they are U.S. citizens, sometimes place themselves outside these symbolic boundaries. Still, youth in more disadvantaged social locations sometimes appropriate markers of Americanness in strategies of what we call "defensive inclusion," employing symbolic boundaries of hard work, multiculturalism and birthplace to contest perceived social boundaries of race and class that might exclude them from the core of "Americanness." Our findings suggest that researchers should include measures of economic national identity in future survey-based work and examine discursive practices of defensive inclusion in fieldwork.
\end{abstract}

Keywords: national identity, race, comparative, United States 


\section{Introduction}

What does it mean to be "American"? Scholars of immigration and nationalism have questioned the usefulness of "ethnic" and "civic" distinctions to categorize the national identities of European countries. But in debating the content of American identity, research still tends to dichotomize Americanness as either "civic" —open to anyone and based in shared belief in a common 'national creed' of core political principles — or "ascriptive," based on traits over which individuals have little control, such as race or ancestry. For some, immigrants' naturalization indicates that political allegiance trumps attributes like religion or ethnicity in defining Americanness; others note that the first Naturalization Act limited citizenship to "free, white persons," an ascriptive, racialized notion of Americanness. Scholars working at this "macro" level of Americanness have examined law, state institutions, elite legislative and judicial actions, political discourses and the media (e.g., Gerteis \& Goolsby 2005; Smith 1997).

But what of ordinary people's views? Do American citizens who occupy different social locations, which we define as a combination of their economic situation, minority status, and prospects for the future, share conceptions of the content of national identity? The limited existing research has largely leveraged survey data, analyzing polls such as the General Social Survey to probe people's opinions through questions asking how important it is to "respect American laws" (more civic) or "to be Christian" (more ascriptive) for being "truly American." The survey research provides rich data, but tends to use the conceptual dichotomy of civic inclusion and ascriptive exclusion, even as researchers introduce multiple measures within the two categories (e.g., Schildkraut 2011; Theiss-Morse 2009; Wright, Citrin, and Wand 2012).

We argue that an inductive approach, grounded in in-depth interviews with open-ended questions, allows us to identify alternative conceptions about the content of national identity. This 
includes narratives of economic Americanness situated in people's personal circumstances and comparisons with others. Drawing on narratives also reveals how people deploy symbolic markers of economic standing, civic inclusion, race, multiculturalism and birthplace to produce a collective "we" that can include or exclude them in ways more complex than civic/ethnic dichotomies suggest. We are primarily interested in what constitutes "Americanness" in people's minds—-the content of American identity—rather their own (or others') identification as “American," though in many cases such conceptions are entangled.

Empirically, we focus on young people coming of age in a time of unprecedented economic inequality and ethno-racial diversity in the United States. We compare US-born undergraduates attending Ivy League universities, most of whom come from privileged homes with collegeeducated parents, to teenaged US citizens who are children of immigrants living in predominantly poor and low-income families. One group, through its admission and enrollment at Ivy League colleges, embodies high status and idealized qualities of America; the other group's inclusion in Americanness has been contested (e.g., Huntington, 2004). The juxtaposition allows us to analyze how a group potentially stigmatized by the social boundaries of race, economic condition and immigrant background views Americanness compared to a group that has experienced educational success and can anticipate socioeconomic success. ${ }^{1}$

In the interviews, those who have experienced educational success express inclusive views of Americanness, emphasizing civic membership, agency, and opportunity, especially economic opportunity, presumably open to all in a democratic United States. Their sense of opportunities is often folded into definitions of civic membership through voting, community engagement, freedom, and knowledge of US history. They feel comfortably at the center of American identity, and their vision is an inclusive, multicultural America. Taken at face value, such inclusive views auger well 
for an evolving civic Americanness; some of these youth will move into elite positions in politics, media, business and education, shaping discourses of American identity. Yet the overlap of civic membership with economic opportunity, at times conflating the two, can exclude those living with or facing more limited opportunities.

Indeed, youth from immigrant families rarely link economic opportunities with a civic, creedal Americanism. Rather, when they speak of material conditions as part of Americanness, they mention current income, home ownership and paying taxes. Given the modest socioeconomic situation of many, this produces sentiments of exclusion for some, which can be overlaid with white-identified racial or cultural notions of Americanness. These youth are less likely to use the language of "we" and "us" and more likely to use pronouns like "they" and "them" when describing Americans. In response, some engage in strategies of what we call "defensive inclusion”, employing symbolic boundaries of hard work, multiculturalism and birthplace to contest perceived social boundaries of race and class that might exclude them from the core of "Americanness" (Lamont \& Molnar 2002).

We thus identify important but understudied economic narratives of Americanness, adding to the knowledge base developed by survey research. Depending on social location, economic notions of Americanness also overlap with other boundaries: whiteness for some immigrant-origin youth; civic membership for Ivy League students. Thus, components of national identity that survey research often tallies as distinct can be mutually constitutive rather than competing. At the same time, youth in more disadvantaged social locations can appropriate markers of Americanness in strategies of defensive inclusion, revealing nuanced identity work.

\section{Conceptualizing and Measuring the Facets of "Americanness"}


Interest in, and the contrast between, civic and ascriptive American identity is driven by America's long history of race-based exclusions from citizenship and rights, as well as its history as an immigrant-receiving country that has absorbed millions of "foreigners" into the nation (HaneyLopez 1996; Smith 1997). Much of this work has focused on laws, elites' discourses in legislatures or courtrooms, or media narratives, with less attention paid to the views of ordinary people.

Researchers who do study ordinary Americans' views use opinion polls to ask whether certain qualities are important for being American, such as birthplace, citizenship, long-term residency, speaking English, Christianity, respect for political institutions and laws, feeling American, or American ancestry. Survey data allow researchers to probe the degree to which people's views vary, the reasons behind variation, and the consequences for policy preferences (e.g., Kunovich 2009; Schildkraut 2005, 2011; Theiss-Morse 2009; Wright, Citrin and Wand 2012). Some researchers identify moderate, but arguably consequential differences in ascriptive definitions of Americanness. For instance, Americans are divided on whether being Christian (52.1\%) is important for being American (Wright, Citrin and Wand 2012: 473; Theiss-Morse 2009). Other scholars underscore substantial similarities: large majorities agree that civic beliefs, such as respect for American institutions and laws, are a fundamental part of being American (Schildkraut 2011; Wright, Citrin and Wand 2012).

Among researchers who use qualitative, open-ended interviewing to understand identity, a fair number are scholars of immigration. Their focus tends to center on ethnic rather than "American" identity. Traditionally, Americanness was the absence of (other) ethnicity; today, the dominant view is that immigrants and their children can be part of an American "mainstream" while retaining ethnic attachments and concomitant cultural practices (Alba \& Nee 2003; Kasinitz, Mollenkopf, Waters, \& Holdaway 2008). Some studies highlight, however, how racial norms make 
certain groups feel like outsiders or "forever foreigners," even after generations in the United States (Jimenez 2010; Tuan 1998); other research ties feelings of exclusion to American imperialism or colonial history (Espiritu, 2003; Maira, 2009). Given interest in ethnic or hyphenated identities as well as ethno-racial exclusion, the actual content of Americanness remains somewhat of a black box. While descriptively rich, these studies also tend to focus on one ethno-racial group, implying a well-off white comparison point, but not directly analyzing the views of those imagined to epitomize Americanness.

Comparative sociology pays more attention to the content of national identity through the use of boundary analysis (e.g., Alba 2005; Bail 2008; Wimmer 2013; Zolberg and Woon 1999). Alba (2005), for example, identifies language, race, religion, and citizenship as boundaries of membership that vary across countries for those of immigrant origin. We draw inspiration from this approach to argue for greater attention to material aspects of national identity, notably how economic opportunities for mobility or one's current economic condition shape conceptions of what it means to be American. Historically, the Protestant ethic, property ownership and the ability to control one's labor have been associated with Americanness (e.g. Huntington 2004; Shklar 1991; Smith 1997). Today, second generation youth may invoke cultural citizenship or consumption to mark their inclusion within the boundaries of Americanness (Maira, 2009; Park 2005). Yet surveys do not usually include questions on whether employment, wealth or economic mobility makes someone truly American. One exception, Schildkraut's (2011) 21st Century American Survey, finds that $91 \%$ of respondents think "pursuing economic success through hard work" is an important part of American identity. The notion of class is central to boundary approaches within cultural sociology (e.g., Lamont 1992, 2000), but social location and economic narratives have been insufficiently studied in existing comparative or survey work on Americanness. 
Are economic notions of Americanness inclusive or exclusive? In Schildkraut's survey, economic conceptions are viewed as positive, inclusive attributes because they do not explicitly link to nativity or a particular ethno-racial or religious background. Yet the language of opportunity and economic condition can exclude, through the arbitrariness of birth in a richer or poorer family and through structural inequalities over the life course. A few qualitative interview studies note, in passing, that some immigrants and their US-born children view economic opportunities as a positive aspect of an American creed, while others criticize the American Dream as an illusion, linking "Americanness" to middle-class whites (Bloemraad 2013; Kasinitz, et al. 2008).

The ambiguity of economic narratives raises the question of whether other national identity traits can also vary in valence, depending on how they are deployed (Gerteis \& Goolsby, 2005). Dichotomies of civic and ascriptive national identity are presumed to be inclusive and exclusionary, respectively. While much of the boundaries scholarship centers on how symbolic boundaries maintain and normalize social boundaries, Lamont and Molnár (2002: 186) remind us that symbolic boundaries can be used "to contest and reframe the meaning of social boundaries." Indeed, through a process we call defensive inclusion, we find that some children of immigrants recognize but challenge others' conceptions of Americanness as white and well-off. Ironically, this defensive inclusion often relies on attributes assumed to exclude foreigners, such as being born in the United States and speaking with an American accent. Strategies of defensive inclusion also underscore how boundary-making around national identity is a relational process.

\section{Methods and Research Design}

Our data come from semi-structured, in-depth interviews collected during two research projects, one with 76 US-born undergraduates attending one of two Ivy League universities, and 
another with 72 Mexican-, Vietnamese- and Chinese-origin teenagers living in the San Francisco Bay Area in predominantly poor or working-class immigrant households. ${ }^{2}$ The significant overlap in methods and data collection, combined with common interest in the meaning of Americanness, provide a rich empirical basis for comparing the views of young people living in distinct social locations.

Ivy League students were recruited for a project on elite students' understandings of race and meritocracy via emails to housing units that serve random groups of students and through a subsequent snowball sample for which at most one additional person was recruited through any given respondent. Thirty of the Ivy League university students were racial minorities, and 46 identify as white American. Twenty of the 30 students of color had at least one immigrant parent. Most Ivy League students came from privileged families: $86 \%$ had at least one parent who has a four-year college degree (in contrast to one-third of American adults who hold a bachelor's degree).

The immigrant-origin teenagers, all of whom were high school students in northern California, were recruited through outreach in high schools, social media, ethnic media, community organizations and snowball referrals as part of a project on political socialization in mixed status families. Almost all teens were US-born and all were American citizens at the time of the interview. ${ }^{3}$ Over half (57\%) lived in households where the reported household income was under $\$ 40,000$ a year, well below the national median of about $\$ 60,000$ at this time, an amount that usually supported four or more family members in one of the most expensive housing markets in the United States. ${ }^{4}$

Both projects used semi-structured, in-depth interviewing techniques. For our analysis, we focus on that part of the interview transcript that records young people's answers to the question "What does it mean to be American to you?" (Ivy League students) or "In your mind, what does it 
mean to be American?" (teens). Answering the abstract question of what makes someone American left open diverse frameworks for responding: some people answered conceptually; others thought about what makes them American compared to others, such as their immigrant parents or people encountered outside the United States; still others answered by defining what makes certain people not American. Respondents were encouraged to share a full range of thoughts or reactions, with interviewers using non-verbal encouragement or explicit probing to elicit examples, caveats or elaborations.

We engaged in systematic analysis of the interview data through a series of steps. All interviews were transcribed and coded, as separate groups, by one co-author using the qualitative analysis software Atlas.ti. Each author then generated memos of emerging themes within just that group. We subsequently exchanged memos and all quotes related to Americanness, to check the interpretation of the interview data and work to a common coding scheme. These discussions led to a second round of interpretative analysis over concepts and valence as well as a common coding scheme to generate simple comparative statistics.

\section{“Opportunity" versus "Money and More Rights" as Americanness}

About half of Ivy League and high school respondents defined what it means to be American in civic terms. We coded as "civic" responses that mentioned participation in democracy, rights and freedoms, equality, pride in country, faith in the US government, participating in one's community, and/or knowledge of US history. For example, Dylan, a white Ivy League student, explained, "I think [to be American] means to take some pride in our country's history. To want to participate in government... To feel some kind of social responsibility, to want to vote, to want to reach out to charitable causes within the country." Sabrina, a Mexican American teen, listed, 
"Getting into problems that are going on in the state. Voting. Helping people out." Whether attending an elite college or in high school, youths' narratives of Americanness shared civic conceptions, perhaps reflecting civic education curricula and broader influences of political culture. This resonates with existing survey research.

Ivy League and teen second-generation students differed, however, in how they linked civic attributes to other characteristics of Americanness. Language about the United States as a "land of opportunity" stood out. ${ }^{6}$ A third of the Ivy League students discussed economic or personal opportunity when asked what it means to be American, in contrast to just four second-generation teens (6\%). Ellen, a college student, said that being American is " $[\mathrm{To}]$ have unlimited opportunity. I like being able to shape your own life." More than a fifth of Ivy League respondents gave both civic and economic opportunity definitions of Americanness, often in the same breath, conflating civic membership with opportunities for economic advancement, which were perceived to be abundant in the United States. For example, Brianna, a white student, responded to the question, "What does it mean to be American, to you?":

Freedom. Opportunity. A say in what happens to the country. The ability...to break out of a social class and advance in society. The American dream....Having the ability to pursue whatever you want to pursue, and have some kind of hope that it will happen.

Brianna intersperses and integrates civic dimensions - freedom and democracy ("a say in what happens to the country") - with language of class mobility. Moreover, for Brianna, being American means hope that mobility and achieving one's dreams will happen.

Some Ivy League students of color also invoked civic understandings and economic opportunities. Shuyi, a Chinese American, said: "It means that my family and I have an opportunity to succeed at whatever we want to succeed at, to fulfill the American dream... And to be respected 
for the value we contribute to society. To expect that our government is accountable to us as citizens.” Like Brianna, Shuyi links the political and opportunity systems in defining Americanness. Given that the "American dream" is a story of social mobility in the popular imagination, Shuyi's definition is perhaps shaped by her experience as the first in her family who will complete college (and at a prestigious university) as well as her likelihood of attaining a professional career.

Most Ivy League students who talked about opportunities did not mention stratified access. Only three students of color and two white students out of 76 suggested that opportunities could be stratified. These five students made a distinction between the ideal - what some might call the American creed - and a reality that can fall short. For example, Jean, a white student, said being American is "The idea [of] equality, freedom, everyone has opportunities, a value of diversity, a value of multiculturalism, the idea anyone can make it. So I think it's a vocabulary that we all have. ...Whether or not those values are actually realized is another question." The in-depth interview data help illuminate overlapping and mutually constitutive understandings of Americanness: Jean, like students who did not qualify their answers, still brings together a set of characteristics in a package of "Americanness" where civic attributes and a multicultural outlook link to a language of opportunities — the idea that "anyone can make it." In this "package" of Americanness, success and chances of success are as available as the right to vote or free speech.

In articulating what "American" means, almost all Ivy League students placed themselves comfortably within the boundary of Americanness. Jean talks about Americanness in the first person ("a vocabulary that we all have"). Using the pronouns "we", "us", and "I", Ivy League students demonstrate a sense of agency, both in individual advancement and civic participation. One-third of Ivy League students, whether white or racial minorities, explicitly used "us" or "we" when describing what it means to be American; just one white student and three students of color 
used the words "they" or "them." Of these four, three also used "us" or "we" in their answers. Elizabeth, a white student, used both in responding to the question, "What does it mean to be American, to you?":

I have the freedom to choose what I want to do....I have been provided with a lot of opportunities to succeed ...I think that many things that are inherent in American society ...help people to explore different paths and, therefore, choose how they will succeed....

Even though Elizabeth uses the pronoun "they" once, her response communicates a feeling of inclusion in the freedoms and opportunities that she sees as inherent in the United States. In talking about people choosing "how they will succeed" (our italic), it seems like success is a given. Elizabeth's family background - she grew up with two parents who hold Master's degrees - does not come up when she describes the opportunity structure. Her positive outlook suggests a fair system in which people succeed because of talent and hard work.

Most second-generation teens, the majority of whom were growing up in low- or modestincome households and all of whom were youth of color, did not use mutually constitutive language of economic opportunities and civic traits to describe what it means to be American, and they were more likely to use "they" and "them" than "we". When teens invoked economic language, most tended to use it as a marker of current economic condition or economic contributions through hard work. For some, it also carried an exclusionary edge, since a focus on current economic condition made it more difficult for them to be included in their own conception of Americanness. Marco, who is a U.S. citizen by birth, but whose Mexican-born parents are undocumented, said, "Mostly... they [Americans] live in quiet areas. Most of them have bought their homes. They live peacefully, not in places where there are shootings at every hour. Where they live, nothing like that happens." Given his own situation, living in a neighborhood with a high homicide rate where his family rents 
poor-quality housing, Marco distinguishes himself from how "they" live and concomitantly, from being truly American. Indeed, more teens linked being American specifically to working or wealth than to voting or patriotism. ${ }^{7}$

Other teens overlaid economic condition with race in a way that excluded them. A young Latina, Marissa, emphasized race when she said, "Like, when they say that it's white, and like, being higher and everything, money and more rights." For her, race (ascriptive), class and rights (civic) are mutually constitutive. For other teens, the link between race and Americanness was categorical, eliding other characteristics. Asked, "What does it mean to be an American? What comes to mind?" one young man answered, "A white person." None of the Ivy League students mentioned race when asked what it means to be American; twelve teens did (17\%). For these teens, despite their U.S. citizenship, minority status places them outside the qualifications of being American.

Marissa's answer, like that of Marco and 20 other teens (31\%), is also notable for the use of the pronoun "they" to describe Americans, setting Americans apart from themselves. Only six teens (8\%) described Americanness in the first person, in sharp contrast to the Ivy League students. Teresa, a Mexican American teen, responded to the question of what it means to be American by saying, "I'm actually not quite sure. I just say I'm American, because I grew up here. I grew up with their laws, their status, their holidays." Although born, raised and educated in the United States, Teresa does not talk about what is ours, but rather about their laws and holidays, even when she calls herself American. Responses like this suggest that second-generation and Ivy League respondents view their location in relation to the core of Americanness quite differently, with the former more distant and the latter closer to its center. 
Despite some teens' language of exclusion, others articulated narratives of defensive inclusion to place themselves within the boundary of Americanness. They hinted that they or their parents might be perceived as outsiders, but then they made an argument for inclusion. Some invoked the notion of "hard work," a condition tied to productivity in the economic system. A Mexican American teen with undocumented parents said, "Well, to me, being American is like living in America, and working in America... Even if you are undocumented, you are still American. You are still paying taxes and all.” Tom saw his Vietnamese-born naturalized parents as American "because they have a job here, and citizenship, and they got their degree" from a local college. Various measures of economic contribution - a college degree, working, paying taxeswere used to bolster claims to Americanness. As we outline in the next section, other students employed cultural and ascriptive forms of defensive inclusion.

\section{“The Multicultural Aspect”: Cultural Inclusion and Defensive Diversity}

Beyond civic, economic or racial characteristics, cultural definitions of Americanness were common. Over a third of Ivy League students (39\%) and nearly half (46\%) of second-generation teens mentioned some cultural aspect to Americanness. We coded as "cultural" mentions of diversity and multiculturalism, customs (e.g., foods, holidays, and comportment), familiarity with American media, popular consumption, and speaking English. Tim, a white Ivy League student, said, "It means that I'm sort of in tune with the American media.... I'm an American consumer, exposed to everything in America." Vincent, a Chinese American teen, expressed civic and cultural conceptions, "All this freedom we have, I would say is the definition of being American. ...And just like...how diversity is pretty good." 
While overall percentages of "cultural" responses were similar, close analysis of the interviews reveals differences in the way Ivy League students and second-generation teens use culture to delineate the boundaries of Americanness. Ivy League students were more likely to bring up abstract notions of diversity and multiculturalism; teens were more likely to bring up specific cultural characteristics associated with the United States. Twenty-six percent of Ivy League respondents brought up diversity or multiculturalism, with a slightly higher proportion among students of color (29\%) than white students (23\%); just one in ten second generation teens (10\%) did so. Among Ivy League students, diversity was always mentioned in an inclusive, positive way. Ernesto, a Latino from New York, said:

I like to think of America as a nation of many nations. That's my being happy and excited about it. But I'm also pretty aware of how other people view America. So when I think America, I always think of George Bush. Like, don't mess with Texas [gun sounds], you know? The two pistols and Yosemite Sam, that whole rhetoric.

Ernesto rejects others' portrayals of Americanness-in this case, a southern, tough, gun-bearing, politically conservative version. Instead, he invokes one that he feels 'happy and excited' about, "a nation of many nations." Stephanie, a white student from the Midwest, said, "I definitely think that part of America is that it's a very multicultural society... If you look at American culture and American society, as I have... in comparison with other countries that I've visited ...the multicultural aspect is huge." White students like Stephanie embrace diversity and multiculturalism almost as frequently as Ivy League students of color. This demonstrates the mainstreaming of diversity among those in elite positions (Alba \& Nee 2003; Berrey 2015).

Teens were more likely to link Americanness with specific cultural practices. As one Vietnamese-origin teen explained: 
Well, there are certain things that are 'American.' ...Everyone wears jeans. You know, what we call football in other countries, [Americans] call soccer. And like Americans know the English system of measurement, not the metric system...

Other teens articulated Americanness as mass or popular culture, as when one explained being American means "eating American food, and hanging around with American people, and doing the American way," which he elaborated to mean participating in American holidays. In these narratives, culture is largely stripped of ethnicity and can be adopted by many U.S. residents, including immigrants, to join a relatively inclusive "mainstream."

Some teens, however, saw a harder barrier of exclusion - or at least distance - between their immigrant backgrounds and (at times stereotypical) views of American culture. A US-born teen with Chinese-born parents said, "To be American, you have to pretty much know... the aspect of culture. I don't think I'm truly American. I mean, from what I've seen of Americans nowadays, they like rap, which I do not like at all." In trying to articulate what, precisely, was cultural about being American, many teens relied on examples from their family life, like Vinh, a young Vietnamese American woman, "[S]ome immigrants who just become citizens on paper sometimes wouldn't fully understand American culture. For example, a few weeks ago, I was having a sleepover and my mom didn't like it. She said, 'In Vietnam, we never slept over, it was weird'.” Vinh's parents are "citizens on paper," but her mother's negative view of sleepovers becomes a cultural marker of being less American.

In survey research, knowledge of English and being Christian are the two most common "cultural" measures of national identity. No respondent, in college or high school, mentioned Christianity as part of Americanness. However, twelve second-generation teens spontaneously mentioned knowledge of English or accent in abstract discussions of being American; many more 
raised language in discussing whether their parents were American. A teen with Chinese-born parents said that she does not see her parents as American, “because they don't speak English very well and they still retain most of their Chinese culture." A young Latina, asked whether she thinks of her naturalized U.S. citizen parents as American, responded, "I think of them as more Mexican than Americans, because they were born over there..., and they don't really speak English well." Conversely, teens sometimes used language as a marker of their own proximity to true Americanness. One explained, "Basically I think of myself as Mexican American, both. Because I've done everything here in America, I go to school here, I live here, I was raised here. I learned English at a very early age. I don't even have an accent.” Another teen, born in the United States to Chinese immigrant parents, echoed, “I think of myself as Americanized. Like when I speak I don't have an accent." Only two Ivy League students mentioned language, and neither raised it as a strong marker of inclusion or exclusion.

Teens' greater emphasis on culture and language is not surprising given that they are growing up in immigrant households; the families of most Ivy League students had been in the United States for multiple generations. Yet teens' answers shed new light on the Ivy League students' answers, underscoring the value of comparing those of recent immigrant origins to those without. Although the college students' multicultural sensibilities mean that they do not use cultural attributes to exclude, the fact that they rarely mention specific cultural attributes implies an American mainstream that is unquestioned or even unseen. The children of immigrants instead face the question of whether the practices and norms of their families fall within the American mainstream, however that might be conceived. Teens' responses suggest that cultural differences may play a stronger role in demarcating Americanness than an ideology of multiculturalism or 
diversity would suggest. The sense of straddling a boundary, of being apart from 'them' but perhaps part of the 'we,' underscores the artificiality of simple inclusion/exclusion dichotomies.

While second-generation teens were more likely to see culture as a means of exclusion, some expressed a cultural form of defensive inclusion. In these cases, teens used a language of defensive multiculturalism to combat others' perceived racialized understandings of American as white. A Mexican-origin teen explained, "The image that I identify with being American is, of course, a white person. [But] it is a mix of cultures." A Chinese American teen, without any prompting about race, said, "I think being American doesn't necessarily mean to be white. Like, if you grew up here, you grew up in a very diverse place.... And if it wasn't this diverse, it wouldn't really be America." While the Ivy League students uniformly used diversity to draw a wide circle around who can be American, teens tended to view the value of diversity in relational terms, employing multiculturalism as a bulwark against perceived exclusions. Diversity is positive for teens, but the interviews suggest that it derives its saliency from offering an alternative to equating American with whiteness, which some perceived as the dominant understanding.

\section{American Residence, Citizenship and Birthplace}

Theorists treat conceptions of national identity based on residence, citizenship and birthplace as fundamentally different. Residence suggests an inclusive form of membership that ignores race, class, culture, religion or even legal status. Citizenship is more restrictive: it excludes noncitizens, but is blind to race or other socio-cultural attributes in the contemporary United States. Birthplace is the most restrictive since it excludes all immigrants, including naturalized citizens. Indeed, some theorists suggest that political membership based on birthplace is a modern form of ascriptive feudalism: it is entirely beyond the individual's control (Schuck \& Smith 1985; Shachar 
2009). Our respondents saw things differently from theorists. Many, whether at elite colleges or in high school, treated residence, citizenship and birthplace as similar, minimalist conditions of inclusion. And, in contrast to theorists' argument of birthplace as ascriptively exclusionary, some teens used birthplace as a third form of defensive inclusion against those who might question their Americanness.

Just under one-third of Ivy League students described Americanness as citizenship, residence, or US birth, in a minimalist answer without exclusionary, nativist or racial character. The brevity and tone of responses suggested little thought about the content of Americanness. Nisha, an Indian American undergraduate, said being American is "Just to be born in this country," and Serena, a white undergraduate said, "I guess to be born in America." Similarly, a second-generation teen said, "I guess someone who was born here." At times birthplace and residence were conflated. Cristina, a Mexican American teen, said being American means "that you were born here in America, that you were raised here." Although birthplace is "ascriptive" in that you cannot control it, for these young people, it was inclusive; they did not presume particular ethnoracial, economic or cultural traits.

Responses related to residence or formal citizenship had a similar inclusive orientation, although the geographic circle of who is included as "American" shifts. For Haley, a white undergraduate:

[I] don't feel like I have a strong patriotic identity at all. I guess technically ...you live here, and that's pretty much it. For some reason it just never really stuck with me that there's any sort of American thing.

Dexter, an African American, gave a slightly different response, "I don't think that there's a lot tied to that. I think that to be American, means... you live here and you're an American citizen, or 
maybe not even that you live here, but you're an American citizen...." Both students underscore minimalist notions ("technically" for Haley, "not...a lot tied to that" for Dexter), removing cultural content and ethnoracial or economic attributes from their definitions. In a similar way, Trinh, a Vietnamese American teen, replied to the question of what it means to be American with a question-inflected response, "I don't know, someone who is living here?"

Analysis of the interviews did reveal one notable difference: some teens harnessed discourses of birthplace citizenship in a defensive move; Ivy League students did not. Many of the 45 teens $(63 \%)$ who referred to birthplace, citizenship or place of residence seemed to share elite students' minimalist views. But a minority used the absolutism of birthplace to challenge exclusions they had faced or imagined they might face. One young woman with Mexican-born parents described American as, "Well, being born-- I am US-born... I was born here, but I feel like... other people see me as Mexican. Like if a white girl sees me, she'll say, 'Oh yeah, she's Mexican,' even

though I was born here.” A teen with Chinese-born parents said, “Although... I look Chinese, I still feel American because I was born here." Use of birthplace is thus an alternative form of defensive inclusion, in addition to the appeals to hard work and multiculturalism articulated by some secondgeneration teens.

\section{Social Location and Blurred Boundaries}

Our comparison is not generalizable to the US population or all young people, nor is it meant to be. We use the idea of differential social location to probe similarities and differences in national conceptions among young Americans at an age in which they are developing their identities and worldviews. Our conceptual categorization simplifies, however, a messier empirical reality: some Ivy League students came from less privileged backgrounds and from immigrant 
families, and a small sub-set of teens were growing up in more affluent households. Careful analysis of interviews with respondents who blur our social location distinction hints that more secure economic status might mitigate, though not eliminate, racial or immigrant exclusions.

Among teens, the eight living in better-off households (earning over $\$ 100,000$ per year) did not articulate a sense of economic exclusion from Americanness; most, in defining what it means to be American, included themselves in that definition. Mary, whose Vietnamese-born parents owned their own business, provided a vague, civic response to the question of what it means to be American, "I guess just someone who is very patriotic." The interviewer followed up by asking whether Mary considers herself American. She answered, "Yeah, I guess so, because I am born here." A few of the more well-off teens did nevertheless signal possible cultural and racial distance. Roxana, whose naturalized father initially entered the United States without legal papers, was among the most affluent children of Mexican immigrants we interviewed, living in a roomy suburban home thanks to her father's unionized construction job and her mother's employment in a hospital. Asked what it means to be American, Roxana drew on a teacher's example to deploy language of defensive inclusion:

I guess [it means] someone who was born here. I'm going to go back to my junior year teacher, because she is Mexican American. But when they ask her, 'Oh, what are you?' She is like, 'I am American and Mexican,' because she was born here, but her ethnicity and her background, her culture is Mexican... So I guess you could say someone American is someone who is born here, because I kind of like her idea.

Cynthia, whose parents were born in Guangzhou, China and whose father is an electrical engineer, didn't hesitate to call herself an American, which for her meant "I grew up here." If being middle class or wealthy is a hallmark of Americanness for some, growing up in a well-off household might mitigate feelings of exclusion. However, we hestitate to draw strong conclusions, 
given the very limited number of teens in affluent families. We do not know whether teens changed their views when (or if) they finished high school, or whether any beat very slim odds to enter an elite university. Existing research suggests that college experiences move immigrant-origin youth away from self-identifying as "American" and toward ethnic and racial identities (Feliciano 2009). But while this scholarship suggests that labels change, we know less about how experiences beyond high school shape the content of Americanness. We hypothesize that if a respondent gains entrée into an elite university, his or her conception of American identity might shift toward an abstract civic, multicultural and economic opportunity narrative and lessen feelings of exclusion from Americanness. This could happen due to the personal experience of educational inclusion in an institution considered the pinnacle of success and these universities' diversity cultures.

We come to this hypothesis in part because, among the Ivy League students, most students of color spoke of Americanness in ways similar to their white peers. Some at times articulated a sense of marginality, but this was often muted and overcome with optimistic inclusion in the next breath. Recall Ernesto, the child of immigrants, who led his answer with a positive, multicultural view of Americanness, but followed with others' Texan, gun-toting views. Marie, a Haitian American Ivy League student from a working class family, took pains to distinguish her vision of Americanness from alternative ascriptive views, "It's not necessarily that you're born in this country... Definitely not ethnicity, because every ethnicity lives in this country." She instead laid out "this idea of freedom, equality, liberty, and our Bill of Rights, those basic structures that are in government... that we're taught from the very youngest age about, that are part of the American culture." Like some teen respondents, Marie takes the time to reject ascriptive notions of Americanness, but Marie's language does not have the same defensive edge as some second generation teens. In a similar way, Michael, an African American Ivy League student adopted by 
white college graduates, uses his adoption to demonstrate the opportunities and equity that birth in the United States affords:

Our founding principles in some respects, that we're all born equal and we all haveshould have at least - equal opportunities to make the best of ourselves. I feel very fortunate that I was born in the country and a system where I could be adopted and given a chance to succeed. And not everyone has that, but I think that that's the ideal that all Americans strive for.

Michael is one of the few elite students who recognize that "not everyone" has equal opportunities, but like many peers, Michael speaks of opportunity and civic identity in the same breath. We posit that these students' views are shaped by entrée into and experiences within the Ivy League, which is constructed as the epitome of success and future social mobility. It is possible, however, that as Marie, Michael and other minority Ivy League respondents enter the workforce, they may experience racial discrimination that leads them to question the opportunity structure, pushing them away from seeing themselves as American.

\section{Concluding Discussion}

Our findings open new theoretical, empirical and methodological paths to understanding the content of American identity at a time of increasing inequality and diversity. By asking the openended question of what it means to be American, we sought to understand conceptions that spontaneously came to mind for young people. We identify economic narratives of Americanness that can take various forms, such as opportunity, hard work, or success. We also find that separating 'inclusive' and 'exclusive' aspects of national identity is difficult without attention to the subjective meaning that individuals attach to them (see also Gerteis \& Goolsby 2005). Overall, we show that while survey research's rigor in question wording and classification can promote conceptual clarity 
and allow for statistical analysis, more open-ended approaches expose the messiness present in the minds of ordinary people. Even when asked the same question, respondents answer very differently, from the abstract "What is American?" to "What makes me American?" or "What makes them American?" Open-ended questioning provides a holistic understanding of American identity, elucidates the mutually constitutive nature of civic, cultural, ascriptive (especially racial), and economic aspects of national identity, and reveals distinct reference points in defining Americanness, such as experiences of success and social mobility for elites, or immigrant background and economic marginality for others.

Beyond interview- and survey-based approaches, social psychologists show that even those who express an understanding of Americanness as inclusive may unconsciously equate being American with being white (Devos and Mohamed 2014). It may be the case, then, that Ivy League respondents hold unconscious associations that exclude immigrants and their children from Americanness, even while their conscious expressions are inclusive. Further, the second generation teens may perceive exclusion expressed or enacted by dominant groups based on unconscious biases. More research is needed to assess the extent to which implicit, interview-based, and surveybased measures of Americanness are related and influence individual perspectives and behaviors.

A key methodological lesson, then, is the need for a more engaged conversation between the different methodological approaches to studying national identity. Our findings suggest that social location may matter for conceptions of Americanness, and that more attention needs to be paid to economic dimensions, in both inclusive and exclusionary ways. There is a longstanding recognition that economic opportunity and hard work are part of a particular "American Creed." But survey research on national identity rarely taps economic belonging. Our interviews suggest that this is a key facet of Americanism. Moving forward, survey researchers should add measures of economic 
inclusion and exclusion to their survey instruments. Having this option may reveal the importance of economic aspects of national identity, just as providing Americans with a "working class" option reveals significant diversity in class identification (Hout 2008). Our findings also suggest alternative analytic strategies to standard regression models, such as fuzzy-set (Bail 2008) or latent class analysis (Bonikowski and DiMaggio 2016), more attuned to a configurational approach.

Substantively, we emphasize the relational and boundary-drawing nature of Americanness. Ivy League respondents more confidently place themselves at the center of American identity, discussing how "I" and "we" are American. They describe an inclusive Americanness, which welcomes diversity, multiculturalism, and social mobility. Yet elite cultural omnivorousness (Peterson \& Kern 1996) and claims of cosmopolitanism or multiculturalism can mask underlying class distinctions, preferences for particular parts of the world, and racial exclusion (Bell and Hartmann 2007; Gerteis \& Goolsby 2005; Johnston \& Baumann 2007). Ivy League students appear to have internalized the US equal opportunity ideology, incorporating these beliefs into what it means to be American. However, by invoking inclusion, diversity, and economic opportunity, they may exclude Americans who have not been able to avail themselves of supposedly equal "opportunities to succeed." Other research finds that dominant groups are less likely to recognize symbolic boundaries and other mechanisms of exclusion than disadvantaged groups, who feel their exclusion and subordination more strongly (Johnson 2006; Lamont 1992). Our findings also resonate with a growing literature on elite students' belief in "democratic inequality" (Khan 2010) - that is, a belief that unequal outcomes are based on fair competition in which everyone has had an equal chance (see also Warikoo 2016). Those for whom the American economic and political system has worked are likely to identify opportunities for mobility as a key part of what makes the nation unique. 
For their part, more disadvantaged second generation teens express mixed, and at times ambivalent, notions of Americanness. They sometimes see themselves inside the boundaries of membership, based on a civic notion of Americanness or by evoking the moral superiority of work in ways similar to how white, working-class American men tie their sense of self-worth to their ability to provide for their families (Lamont 2000). At other times, teens express feelings of exclusion, due to poverty or racial minority status. Given racially inflected discourses linking minorities to welfare use and claims that Hispanic immigrants lack the proper civic virtue and Protestant work ethic to become true Americans (Huntington 2004), this feeling of exclusion may be predictable.

Some teens consequently engage in narratives of defensive inclusion. They assert their knowledge of English in contrast to their immigrant parents, or they insist that while others may equate "American" with "white," the United States is in fact a multicultural society and that they are American based on birthplace. In drawing upon nativity and speaking English, immigrant-origin teens claim inclusion based on traits usually considered exclusionary markers of national identity. Others draw upon economic notions of "hard work" to include themselves and their parents in Americanness. These teens employ "strategies of expansion" (Wimmer 2008) to place themselves within the boundary of Americanness. In doing so, they assert inclusive symbolic boundaries to contest perceived social boundaries (Lamont and Molnar 2002).

Our research also demonstrates how "economic" conceptions can vary in substantively important ways. In much the same manner that some argue that "civic" identity should distinguish between liberal or republican variants, or between 'action' versus 'identity' republicanism (Smith 1997; Schildkraut 2011), we find a qualitative difference between economic language of opportunity compared to current economic condition or contribution based on having money, 
owning a home, working, paying taxes and the like. Our findings also suggest that one's social location in the United States - determined by class position, race, immigrant background, and experiences of success - shapes distinct economic conceptions of American identity, analogous in some ways to how upper class and working class workers express class-linked understandings of the self (Lamont 1992, 2000). Further research should disentangle the roles of class, immigrant background, race, age, and experiences of success, as the significant overlap in these variables is a limitation of our comparison. Given rising inequality in the United States, scholars need to look much more carefully at the darker and more exclusionary side of economic Americanness. 


\section{References}

Alba, Richard D. 2005. "Bright vs. blurred boundaries: Second-generation assimilation and exclusion in France, Germany, and the United States." Ethnic and Racial Studies 28(1):20-49.

Alba, Richard D., \& Victor Nee. 2003. Remaking the American mainstream: assimilation and contemporary immigration. Cambridge: Harvard University Press.

Bail, Christopher. A. 2008. "The Configuration of Symbolic Boundaries against Immigrants in Europe.” American Sociological Review, 73(1), 37-59.

Bell, Joyce M. and Douglas Hartmann. 2007. "Diversity in Everyday Discourse: The Cultural Ambiguities and Consequences of 'Happy Talk'." American Sociological Review, 72(6), 895914.

Berrey, Ellen. 2015. The Enigma of Diversity: The language of race and the limits of racial justice. Chicago: University of Chicago Press.

Bloemraad, Irene. 2013. "Being American/Becoming American: Birthright Citizenship and Immigrants' membership in the United States." Studies in Law, Politics, and Society 60:55-84.

Bonikowski, Bart and Paul DiMaggio. 2016.”Varieties of American Popular Nationalism.” American Sociological Review 81(5): 949-980.

Devos, Thierry and Hafsa Mohamed. 2014. "Shades of American Identity: Implicit Relations between Ethnic and National Identities." Social and Personality Psychology Compass 8(12): 739-754.

Espiritu, Yen L. 2003. Home Bound: Filipino American Lives across Cultures, Communities, and Countries. Berkeley: University of California Press.

Feliciano, Cynthia. 2009. "Education and Ethnic Identity Formation among Children of Latin American and Caribbean Immigrants." Sociological Forum 52(2): 135-158.

Gerteis, Joseph and Alyssa Goolsby. 2005. "Nationalism in America: The Case of the Populist Movement." Theory and Society, 34(2), 197-225.

Haney-Lopez, Ian F. 1996. White By Law: The legal construction of race. New York: NYU Press.

Hout, Michael. 2008. "How Class Works: Objective and Subjective Aspects of Class Since the 1970s." In A. Lareau \& D. Conley (Eds.), Social Class: How Does it Work? New York: Russell Sage Foundation.

Huntington, Samuel P. 2004. Who are We? America's Great Debate. New York: Simon \& Schuster.

Jiménez, Tomás R. 2010. Replenished Ethnicity: Mexican Americans, immigration, and identity. Berkeley: University of California Press.

Johnson, Heather B. 2006. The American dream and the power of wealth: choosing schools and inheriting inequality in the land of opportunity. New York: Routledge.

Johnston, Josee and Shyon Baumann, S. 2007. "Democracy versus Distinction: A Study of Omnivorousness in Gourmet Food Writing." American Journal of Sociology, 113(1), 165-204. 
Kasinitz, Philip, John H. Mollenkopf, Mary C. Waters, and Jennifer Holdaway. 2008. Inheriting the City: The Children of Immigrants Come of Age. . CambridgeHarvard University Press.

Khan, Shamus R. 2010. Privilege: the making of an adolescent elite at St. Paul's School. Princeton: Princeton University Press.

Kunovich, Robert M. 2009. “The Sources and Consequences of National Identification.” American Sociological Review 74(4): 573-593.

Lamont, Michele. 1992. Money, morals, and manners: the culture of the French and American upper-middle class. Chicago: University of Chicago Press.

Lamont, Michele. 2000. The dignity of working men: morality and the boundaries of race, class, and immigration. New York and Cambridge: Russell Sage Foundation and Harvard University Press.

Lamont, Michele and Virag Molnar. 2002. "The Study of Boundaries in the Social Sciences." Annual Review of Sociology 28, 167-195.

Maira, Sunaina. 2009. Missing: Youth, Citizenship, and Empire after 9/11. Durham: Duke University Press.

Park, Lisa S. 2005. Consuming Citizenship: Children of Asian Immigrant Entrepreneurs. Stanford: Stanford University Press.

Peterson, Richard and Roger Kern, R. 1996. "Changing Highbrow Taste: From Snob to Omnivore." American Sociological Review 61(5), 900-917.

Schildkraut, Deborah J. 2005. Press one for English: language policy, public opinion, and American identity. Princeton: Princeton University Press.

Schildkraut, Deborah J. 2011. Americanism in the Twenty-First Century: Public Opinion in the Age of Immigration. New York: Cambridge University Press.

Schuck, Peter H., and Rogers M. Smith. 1985. Citizenship without Consent. New Haven: Yale University Press.

Shachar, Ayelet. 2009. The Birthright Lottery: citizenship and global inequality. Cambridge: Harvard University Press.

Shklar, Judith. 1991. American Citizenship: The Quest for Inclusion. Cambridge: Harvard University Press.

Smith, Rogers M. 1997. Civic Ideals: Conflicting Visions of Citizenship in US history. New Haven: Yale University Press.

Theiss-Morse, Elizabeth. 2009. Who Counts as an American? New York: Cambridge University Press.

Tuan, Mia. 1998. Forever Foreigners or Honorary Whites? The Asian Ethnic Experience Today. New Brunswick: Rutgers University Press.

Warikoo, Natasha. 2016. The Diversity Bargain: And Other Dilemmas of Race, Admissions, and Meritocracy at Elite Universities. Chicago: University of Chicago Press. 
Wimmer, Andreas. 2008. "Elementary Strategies of Ethnic Boundary making." Ethnic \& Racial Studies, 31(6), 1025-1055.

Wimmer, Andreas. 2013. Ethnic Boundary Making: Institutions, power, networks. New York: Oxford University Press.

Wright, Matthew, Jack Citrin, and Jonathan Wand. 2012. "Alternative Measures of American National Identity: Implications for the Civic-Ethnic Distinction." Political Psychology 33(4): 469-482.

Zolberg, Aristide R., and Long Litt Woon. 1999. "Why Islam is like Spanish: cultural incorporation in Europe and the United States." Politics \& Society 27(1): 5-38. 


\section{Endnotes}

${ }^{1}$ The two groups of young people are thus distinguished by multiple differences in social and symbolic boundaries, which we conceptualize with the term "social location." Our goal is not to pinpoint the independent importance of any one factor (e.g., household wealth, parents' education, racial minority status), but to consider how an arguably idealized group (Ivy League students) and another at times vilified group (teens in low-income immigrant families) conceive of an ostensibly shared Americanness.

${ }^{2}$ Interviews with teens were conducted in 2006 and 2008 and with college students from 2009 to 2011. College students were almost equally divided between sophomores, juniors and seniors. The teens ranged in age from 14 to 18 . Given the study design, we cannot isolate the independent effect of age or life course in conceptions of Americanness. This is an interesting area for future research. ${ }^{3}$ Fourteen youth arrived in the US at a young age. Thirty-five teens are Mexican American, 18 are Vietnamese American and 19 are Chinese American. Youths' parents were undocumented, legal permanent residents, or naturalized citizens.

${ }^{4}$ About 11 percent of teens lived in more affluent households, based on parents' self-reported household income of over $\$ 100,000$ or educated guesses of a family's financial situation based on residence and parents' occupation when parents were unwilling to share their income.

${ }^{5}$ We use the term "Mexican American" (or Chinese or Vietnamese American) as a descriptive term to mean the US citizen children of Mexican-, Chinese- or Vietnamese-origin parents, not as necessarily representing the respondent's personal identification.

${ }^{6}$ We coded as "opportunity" responses that used this word explicitly, or were related to economic advancement or labor market mobility, including mentions of the "American Dream."

${ }^{7}$ Ten teens (14\%) mentioned an economic criterion (e.g., having a house, money, a job, earning a college degree, working, paying taxes), as compared to only eight teens who specifically mentioned voting and eight who mentioned patriotism. 